\title{
Algunos retos en la enseñanza clínica
}

\author{
A. Wojtczak
}

Los talleres que se realizan cada año en los dos días previos a los congresos anuales de la Association for Medical Education in Europe (AMEE) son foros de discusión activa sobre diferentes temas de educación médica, de gran importancia para los educadores médicos

Uno de los aspectos clave tratados en estos talleres ha sido el de la enseñanza clínica, fundamental para asegurar la adquisición de las competencias de los graduados médicos. Es una tarea compleja que demanda una alta cualificación de los profesores. Sin embargo, desafortunadamente, estas tareas son asumidas demasiado a menudo por médicos jóvenes sin experiencia docente propia. Aunque la mayoría de ellos están recibiendo o han recibido una rigurosa formación en conocimientos médicos y capacidades, poseen muy poca o ninguna experiencia docente en la enseñanza clínica, donde el entorno depende de varios factores como el tipo de enfermo, su estado emocional o la receptividad del estudiante. Ello exige una gran experiencia personal del profesor. Después de una viva discusión se puso de manifiesto que todos los participantes, profesores y estudiantes tenían puntos de vista similares sobre los factores que influyen en la enseñanza y en el aprendizaje efectivos de las habilidades clínicas, especialmente de exploración física. Se dijo que después de las estancias clínicas se detectan significativos déficit en la adquisición de dichas habilidades y que la solución podría residir en la organización de los laboratorios de capacidades clínicas. Éstos contribuyen a corregir las deficiencias observadas en el rendimiento clínico de los estudiantes y a reducir las diferencias de conducta entre profesores, un factor decisivo que hace disminuir la motivación de los estudiantes y que puede dificultar su aprendizaje.

Otro tema discutido en profundidad y de importancia crucial en el proceso de enseñanza/ aprendizaje efectivo fue el del feedback. Sin feedback, los errores no se corrigen, las actuaciones correctas no se refuerzan y la competencia clínica puede verse afectada negativamente. Aunque estudiantes y profesores reconocían la importancia del feedback, la mayoría de los primeros aseguraban que el feedback era insuficiente porque muchos de ellos tenían dificultades en darlo, sobre todo cuando se refería a áreas problemáticas. Sugerían que se introdujeran actividades educativadas encaminadas a desarrollar estas habilidades.

Es indudable que las capacidades de comunicación son una competencia nuclear en la educación médica en cualquier parte del mundo. Sin embargo, la enseñanza de estas capacidades constituye todavía un problema pendiente en demasiadas facultades de medicina, que se suele dejar para que se adquieran durante la formación posgraduada, durante la residencia o durante la práctica profesional. Afortunadamente hay buenos ejemplos de esfuerzos crecientes para desarrollar programas de aprendizaje de los estudiantes en esta área. Evaluar cómo los graduados desarrollan sus capacidades de comunicación debe formar parte de la evaluación al final de la formación de grado.

Otro de los temas discutidos y que influye en la calidad de la educación es la valoración de la actividad docente de los profesores por parte de los estudiantes. Se hizo énfasis en que aunque esta valoración resulta necesaria, no es suficiente y no puede consistir en la única medida de la efectivi-
Exdirector del International Institute for Medical Education (IME)

Expresidente de la Association for Medical Education in Europe (AMEE) E-mail wojtczak@cmkp.edu.pl 
dad de la enseñanza. La utilización de múltiples fuentes de información puede proveer una base más exacta y fiable para la evaluación formativa (mejora de la enseñanza) y sumativa (renovación de contratos, promoción) que la utilización de una sola fuente de información. Un abanico de varios indicadores incluiría: valoración por estudiantes y por pares, evaluaciones externas, autoevaluaciones, valoraciones de exalumnos, premios o méritos docentes de los profesores, medición de los resultados, portafolios, etc. El desarrollo profesional del profesor en el futuro depende de la equidad en estas decisiones.

Finalmente, otro de los temas que suscitaron una discusión muy interesante fue el que se refiere a la misión de las facultades de medicina como generadoras de un cuerpo de conocimientos (scholarship) y su relación con la calidad de la docencia. Se puso énfasis en que la generación y posesión de un cuerpo de conocimientos por parte de la facultad o de sus profesores (educational scholarship) no siempre se corresponde con la excelencia educativa, y aunque muchos profesores realizan la actividad académica (scholarly activity), a menudo no son capaces de trasladar sus esfuerzos a la docencia, al desarrollo curricular, a la innovación y al liderazgo educativo. Se dijo que 'dicha actividad (scholarship) sirve como base para el crecimiento del conocimiento' y es una cuestión importante para su discusión en el ámbito académico.

Todos los temas anteriormente comentados deberían tenerse en cuenta en el momento de planificar los programas de formación del profesorado con el fin de estimular sus capacidades educativas y fomentar el liderazgo y la scholarship de los profesores. Los programas de formación del profesorado en educación médica es la única estrategia viable para el fomento de la docencia de excelencia, necesaria en tiempos de creciente competencia entre las instituciones educativas médicas.

\section{Some challenges in the clinical teaching}

The Pre-Conference Workshops that are organized before the opening of the Annual Association for Medical Education in Europe (AMEE) Conferences are the places of lively discussions on different aspects of medical education that are of great importance for medical teachers.
One of such topic that is securing the competences of medical graduates is a clinical teaching. It is a complex task that demands a high qualification of the teachers. However, unfortunately, these tasks are too often assumed by the young clinicians without proper teaching experience. Although, most of them are receiving the rigorous training in medical knowledge and skills, they have no at all or a very little training in clinical teaching where the clinical environment depends on various factors such as a kind of patient illness and his or her emotional state as well as the learner receptiveness. It demands a great teachers' personal experience. It was interesting that during a lively discussion all participants, both teachers and students, have similar views on factors influencing the effective teaching/learning of physical examination skills. It was said that the clerkships leave the significant gaps in possessed clinical skills. The solution has been seen in the organization of clinical skills laboratories that help in filling the confidence gaps in students' clinical performance and cover the differences in teachers' behavior that is deciding factor in decreasing the students' motivation and impede their learning.

The other topic discussed in depth that has a crucial significance in effective teaching/learning processes was an issue of feedback. Without feedback, mistakes are uncorrected, good performance is not reinforced, and clinical competence may suffer. Although both, learners and teachers, have recognized the importance of feedback, yet most learners said that their feedback is inadequate as many of them have difficulty in giving feedback, especially when it centers on problem areas. They suggested the specific educational activities that would help faculty to develop these skills.

There also was no doubt that the communication skills are a core competency in medical education worldwide. However, teaching communication skills is still a challenging area as in too many medical schools these skills are left to be learned after graduation, during internship or when in practice. Hopefully there are good examples of growing efforts to develop learning programs for students. The evaluation of how medical graduates are able to exercise their communication must be part of examination at the end of the undergraduate training program.

Another discussed issue that influences the quality of education is the student ratings of teachers' performance. It was strongly stressed that although it is necessary, it is definitely not sufficient as a source to measure teaching effectiveness. The triangulation of 
multiple sources can provide a more accurate and reliable base for formative (teaching improvement) and summative (contract renewal, promotion) decisions than any single source. The spectrum of various measures includes such as: student and peer ratings, external expert ratings, self-ratings, alumni ratings, teaching awards, learning outcome measures, teaching portfolio. As faculty, your future depends on the fairness of these decisions.

Finally, a very interesting discussion took place on a scholarship as a fundamental mission of all medical schools. It was stressed that an educational scholarship differs from educational excellence and although many educators are involved in scholarly activity, they are often not able to translate the efforts in teaching, curriculum development and innovation, and educational leadership into scholarship. It has been said that 'scholarship serves as the building block for knowledge growth' and is an important issue to be discussed in an academic environment.

All above presented issues should be taken into account when planning the faculty development programs with aim of enhancing the educational skills, foster leadership and scholarship of academic teachers. The faculty training programs in medical education are only feasible strategy for fostering the teaching excellence, necessary in time of growing competitions between the medical education institutions. 